\title{
Resurrection of a Madagascan Dichaetomyia Species (Diptera: Muscidae) and Proposal of a New Replacement Name
}

\author{
With 1 table
}

EBeRHARD ZIELKE ${ }^{1}$

${ }^{1}$ Institute of Biodiversity and Ecosystem Research, Bulgarian Academy of Sciences, 1 Tsar Osvoboditel Blvd, 1000 Sofia, Bulgaria. - eo.zielke@abv.bg

Published on 2016-06-30

\section{Summary}

Dichaetomyia scutellaris (Zielke, 1974) is recognized as a good species, distinct from Dichaetomyia rangeri (Zielke, 1973). The differences between the two species are described and listed in a table. As the name of Dichaetomyia scutellaris is preoccupied by Dichaetomyia scutellaris MaLloch, 1928, Dichaetomyia perineta nom. nov. is proposed as replacement name. Amendments for the existing key to Madagascan Dichaetomyia species are proposed.

\section{Key words}

Dichaetomyia scutellaris, replacement name, Dichaetomyia perineta nom. nov., key

\section{Zusammenfassung}

Dichaetomyia scutellaris (ZIELKe, 1974) kann eindeutig von Dichaetomyia rangeri (ZIELKE, 1973) unterschieden werden und ist als eigenständige Art zu betrachten. Die Unterschiede zwischen den beiden von Madagaskar stammenden Arten werden beschrieben und in einer Tabelle erfasst. Da der Name Dichaetomyia scutellaris bereits von Dichaetomyia scutellaris MALLOCH, 1928 besetzt ist, wird Dichaetomyia perineta nom. nov. als Ersatz vorgeschlagen. Für die existierende Bestimmungstabelle für Madagassische Dichaetomyia Arten werden entsprechende Ergänzungen empfohlen.

\section{Introduction}

When Pont (1980) synonymized the genus Annaria ZielKe, 1972 with the genus Dichaetomyia MALLOCH, 1921 the names of three Annaria species became secondary junior homonyms. Couri et al. proposed replacement names for two of these homonyms. The junior homonym of the third species, Dichaetomyia scutellaris (ZIELKE, 1974) was not replaced, as the species was synonymized by the same authors (Couri et al. 2006) with Dichaetomyia rangeri (ZIELKE, 1973) without any explanation. Thus it is also not mentioned which material of $D$. rangeri has been investigated and which observations have been decisive for synonymizing these two species. However, it is very unlikely that the authors have compared the type material of the two species they synonymized. The holotype of Annaria scutellaris ZielKe (now D. scutellaris (ZIELKE)) has been deposited in the entomological collection of the California Academy of Sciences, whereas the holotype of Annaria rangeri ZIELKE (now D. rangeri (ZIELKE)) was 
permanently located in the entomological collection of the Tropical Institute, Hamburg until early 2015 and is deposited since then in the entomological collection of the Institute of Biodiversity and Ecosystem Research in Sofia, Bulgaria. As the two species differ distinctly from one another the validity of this synonymization has to be questioned. The strong evidence for treating Dichaetomyia scutellaris as a separate species is detailed below.

\section{Results}

Resurrection of Dichaetomyia scutellaris (ZIELKE) from synonymy:

The original descriptions for D. rangeri and D. scutellaris are based on the male holotype of each species only. The differences between the two species extracted from the descriptions (ZIELKE 1973 and 1974) are summarized in Table 1 . The most striking difference is seen in the colour of the scutellum. In D. scutellaris there is a conspicuous contrast between the metallic blue violet scutum and the yellow scutellum, whereas in D. rangeri the scutellum is concolorous with the metallic blue violet scutum. This and the other stated differences in Table 1 document, that $D$. scutellaris and D. rangeri are not synonymous and that they have to be recognised as two different species.

Replacement name for Dichaetomyia scutellaris (ZIELKE) spec. rev.:

Annaria scutellaris ZIELKE, 1974 is preoccupied in Dichaetomyia by D. scutellaris Malloch, 1928 and is herewith given the new replacement name Dichaetomyia perineta nom. nov.

Etymology: The new name of the species is derived from the type locality, the Perinet Reservation in Madagascar.

\section{Conclusions}

The key to Madagascan Dichaetomyia species (CourI et al. 2006) did not include the species Dichaetomyia rangeri (ZIELKE), but misapplied that name for the present species $D$. perineta nom. nov. Their key should be amended at couplet 12 and adapted at couplet 14 as follows:

Table 1: Taxonomic differences between the holotypes of D. rangeri (ZIELKE) and D. scutellaris (ZIELKE) compiled from the published descriptions (ZIELKE 1973 and 1974).

\begin{tabular}{|c|c|c|}
\hline & D. rangeri (ZIELKE, 1973) & D. scutellaris (ZIELKe, 1974) nec MALloch, 1928 \\
\hline \multicolumn{3}{|l|}{ Head: } \\
\hline Face & Uniformly grey white dusted & Red-brown, poorly grey dusted \\
\hline $\begin{array}{l}\text { Slightest distance } \\
\text { between eyes }\end{array}$ & About as broad as anterior ocellus & About twice as wide as anterior ocellus \\
\hline \multicolumn{3}{|l|}{ Thorax: } \\
\hline $\begin{array}{l}\text { Presutural part of } \\
\text { scutum }\end{array}$ & $\begin{array}{l}\text { Three broad, white dusted longitudinal } \\
\text { vittae }\end{array}$ & $\begin{array}{l}\text { Poorly grey-white dusted, from some points of } \\
\text { view with three indistinct greyish white longitu- } \\
\text { dinal vittae }\end{array}$ \\
\hline Acrostichal setae & $0+1$ & $0+2$ \\
\hline Scutellum & $\begin{array}{l}\text { Concolorous with metallic blue violet } \\
\text { scutum }\end{array}$ & Yellow, contrasting to metallic blue violet scutum \\
\hline \multicolumn{3}{|l|}{ Legs: } \\
\hline Mid femur & Three posterior setae & Two posterior setae \\
\hline Hind femur & $\begin{array}{l}\text { No hair-like anteroventral setae in basal } \\
\text { half }\end{array}$ & 3-4 hair-like anteroventrals in basal half \\
\hline \multicolumn{3}{|l|}{ Wings: } \\
\hline Calypters & Yellowish with orange-brown margin & $\begin{array}{l}\text { Upper one whitish, lower one brownish } \\
\text { transparent }\end{array}$ \\
\hline \multicolumn{3}{|l|}{ Abdomen: } \\
\hline Tergite $1+2$ & $\begin{array}{l}\text { Basal half brownish-yellow, apical half } \\
\text { blue violet }\end{array}$ & Ground-colour green with violet reflections \\
\hline Last tergite & $\begin{array}{l}\text { Metallic blue violet with a narrow median } \\
\text { yellowish longitudinal vitta and a weakly } \\
\text { developed yellow apical margin }\end{array}$ & $\begin{array}{l}\text { Basal half blue with violet reflections, apical half } \\
\text { yellow }\end{array}$ \\
\hline
\end{tabular}


11. Postpronotum distinctly yellow and in striking contrast to the colour of the rest of the thorax

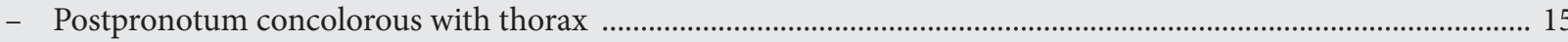

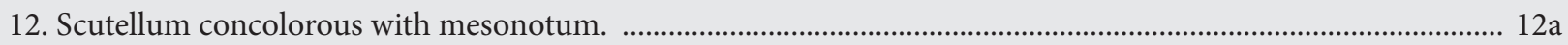

- Scutellum yellow

12a Tergites 3 and 4 with a yellowish median longitudinal vitta; apical half of tergite 5 yellow; sternites yellow (Madagascar) D. (Dichaetomyia) humeralis (ZIELKE)

- Tergites 3 and 4 without median vitta; tergite 5 with a narrow yellow median longitudinal vitta and narrow yellow apical margin; sternites dark (Madagascar) D. (Dichaetomyia) rangeri (ZIELKE)

13. At least anterior half of notopleuron and anepisternum and posterior half of katepisternum yellow; 2 yellow vittae along the dorsocentral rows, reaching the first postsutural dorsocentral seta (Madagasca)

D. (Dichaetomyia) harlekini (ZIELKE)

- Anterior half of notopleuron, anepisternum and posterior half of katepisternum metallic green, concolorous with the rest of the mesonotum; without yellow vittae along the dorsocentral rows of setae 14

14. Hind tibia with 2 anteroventral setae (Madagascar) D. (Dichaetomyia) perineta nom. nov.

- Hind tibia with 1 anteroventral seta (Madagascar) D. (Dichaetomyia) scutellata (SÉGUY)

\section{Acknowledgements}

I am very grateful to an anonymous reviewer for valuable critical comments and helpful suggestions for the improvement of this paper.

\section{References}

Couri, S. C.; Pont, A. C. \& Penny, N. D. 2006: Muscidae (Diptera) from Madagascar: Identification Keys, Descriptions of New Species, and New Records. Proceedings of the California Academy of Sciences, 57: 799-923.

Malloch, J. R. 1928: Fauna sumatrensis (Beitrag Nr. 56) Family Muscidae (Dipt.). - Entomologische Mitteilungen, Berlin 17: 310-336.

Pont, A. C. 1980: Family Muscidae. - In: Crosskey, R. W. 1980: Catalogue of the Diptera of the Afrotropical Region. British Museum (Natural History), London,

ZIELKE, E. 1972: New Muscidae Species from Madagascar (Diptera). - Verhandlungen der Naturforschenden Gesellschaft in Basel 82: 145-163.

Zielke, E. 1973: Limnophora apicalis n. sp. und Annaria rangeri n.sp., zwei neue Musciden von Afrika (Diptera: Muscidae). - Zoologischer Anzeiger, Leipzig 190: 205-207.

ZIELKE, E. 1974: Beitrag zur Kenntnis der Verbreitung afrikanischer Musciden (Muscidae: Diptera). Zeitschrift für angewandte Zoologie, Berlin 61: 1-44. 